\title{
Implementation of Total Quality Management and Its Effect on Organizational Performance of Manufacturing Industries Through Organizational Culture in South Sulawesi, Indonesia
}

\author{
Syamsul Bahri ${ }^{1}$, Djabir Hamzah ${ }^{2}$, Ria Mardiana Yusuf ${ }^{3}$ \\ ${ }^{I}$ Industrial Engineering Department, Engineering Faculty, Hasanuddin University, Indonesia. \\ ${ }^{2,3}$ Management Department, Faculty of Economics and Business, Hasanuddin University, Indonesia.
}

\begin{abstract}
This study aims to examine the application of Total Quality Management (TQM) in a variety of manufacturing companies located in the Industrial Area Makassar in South Sulawesi, Indonesia to see its effect on organizational performance, both directly and indirectly through the mediating variable of organizational culture of the company. Hypothesized that TQM affect organizational performance directly and indirectly through the mediating variable of organizational culture. This hypothesis was derived from nine sub-hypotheses that are constructed in Structural Equation Model and verified by using path analysis. Results from this early stage of confirmatory research revealed that there is no significant direct influence of TQM implementation in various manufacturing companies. However, TQM significantly affect organizational performance via a mediating variable of organizational culture. Thus, current research unearth four interesting findings, in which three of them point to the significance of TQM implementation on organizational culture, organizational culture on organizational performance, and TQM implementation on organizational performance through organizational culture. Finally it was found out that TQM implementation is not directly significant to organizational performance.
\end{abstract}

Keywords: Manufacturing Industry, Total Quality Management, Organizational Culture, Organizational Performance

\section{Introduction}

As the world enter the year 2011, there is a very interesting phenomenon about China, where China will displace Japan as the leader in the field of economics and technology. This fact is reinforced from the study of a business consulting firms, Goldman Sachs, that estimates China's Gross Domestic Product (GDP) would overtook Germany in 2010, surpassing Japan in 2015 and surpass America in 2040 [1].

This is in contrast to the competitiveness of Indonesian industries that have not been able to compete with other countries in the Asia Pacific region. As can be seen in the World Competitiveness Report, which puts Indonesia in the 54th position in 2009 [2] compared to other country such as Malaysia (24) and Singapore (3). Besides that, Indonesian human resource capabilities also has a strong influence on the competitiveness of Indonesian industries because according to IPM, Indonesia ranks 111th in 2009.

This problem worsen by the fact that from 2006 to 2009 there were 66 industrial processing companies that went out of business in South Sulawesi, Indonesia $[4,5,6]$. In line with what have been described in Hitt et al (1997:5), this is due to the company not having sufficient sustainable competitive advantage (SCA) by obtaining above-average profit that finally end up with their bankruptcy. Company's SCA thus need to be maintained and increased in the future as it have brought contribution to the GDP of SOuth Sulawesi as can be seen in table 1 .

Tabel 1. Number of Large and Middle-Size Manufacturing Industrial Company, Contribution, and Growth in South Sulawesi, Indonesia, Year 2006-2010 [6]

\begin{tabular}{|c|c|c|c|c|c|}
\hline Description & 2006 & 2007 & 2008 & 2009 & 2010 \\
\hline Number of Company & 393 & 370 & 361 & 327 & 301 \\
\hline Contribution (\%) & 13.54 & 13.22 & 12.99 & 12.53 & 12.27 \\
\hline Growth (\%) & 7.22 & 4.74 & 8.71 & 3.64 & 6.19 \\
\hline
\end{tabular}

In line with the paradigm shift in the organization from being 'market oriented' to 'resources oriented', one of the ways that could be taken by the company to keep up their SCA is to reorganize its resources in order to survive in the long-term competitiveness by means of implementing Total Quality Management or TQM [7]. Empirical facts show that the implementation of TQM have been recognized as very significant in creating enterprise excellence worldwide. Several previous studies have shown that the effective implementation of TQM do have positive effect on employee motivation [8], increase employee satisfaction and decrease 
Implementation of Total Quality Management and Its Effect on Organizational Performance of employee turnover [9], reducing costs and improving business performance [10], managerial performance [11], and improving the quality of human resources [12].

Some experts argue that the success or failure of the implementation of TQM is largely influenced by cultural factors $[13,14,15,16]$. This is because TQM is basically a program that requires organizational transformation that could only be achieved by changing organizational culture, processes, and beliefs [14].

Evidence [17] have give a remainder that the quality gurus such as Deming, Juran, Feigenbaum, Crosby and Ishikawa have suggested that companies wishing to implement TQM effectively have to have patience. It has been widely accepted that the TQM program is a long-term program, as it takes time and effort to implement organizational change. Organizational change is most needed is related to this cultural change [17, $18,19]$.

Studies linking the implementation of TQM and organizational culture concluded that TQM is effective in developing a quality culture and cultural elements of the success of the process improvement [20]. Besides the dimensions of culture, TQM implementation do have real contribution to improving quality performance and business performance [15]. Furthermore, management style that being supportive would also ensure effective implementation of TQM [21].

On the basis of differences in theory and research findings on the implementation of TQM, current research is interested in studying the implementation of TQM and its effect on the performance of the manufacturing industry in South Sulawesi, Indonesia. In looking at the effect of the implementation of TQM on organizational performance, current analysis would try to unearth both direct and indirect linkage through intervening variables of organizational culture.

\subsection{Total Quality Management (TQM).}

\section{Theoretical Review}

TQM could be defined as an approach in doing business that attempts to maximize organizational competitiveness through the continuous improvement of products, services, people, processes, and environment [22]. Alternative definition [23] state that TQM could be seen as a means of continuous performance improvement at every level of operation or process, in each functional area of an organization, using all human resources and capital available.

Before discussing more about quality and quality management, it is a good idea to review some leaders or pioneers in the field of quality management as summarized in Table 2 below:

Table 2. Quality Management Gurus

\begin{tabular}{|l|l|l|}
\hline Pioneer & Year & Quality Management \\
\hline Ellias Whitney & 1900 & Traditional Approach $\rightarrow$ Product Inspection. \\
\hline F.W. Taylor & 1900 & Management Science. \\
\hline Walter Shewhart & 1924 & Control Chart $\rightarrow$ Product Inspection \\
\hline W.E.Deming & 1950 & 14 Principles in Quality / PDCA (Plan, Do, Check, Action). \\
\hline AV. Feigenbaun & 1961 & Concept: Make it right at the first time (One of Basic TQM). \\
\hline Koaru Ishikawa & 1967 & $\begin{array}{l}\text { Statistical Approach in Quality Control, Ishikawa Diagram (Fishbone } \\
\text { Diagram). }\end{array}$ \\
\hline Yoji Akao & 1972 & QFD (Quality Function Deployment). \\
\hline Philip B. Crosby & 1979 & Top Management in Quality. \\
\hline Shiego Shigo & 1979 & Product Quality Control $\rightarrow$ Total Quality Control. \\
\hline Genichi Taguchi & 1980 & Kaizen (Continuous Improvement), Robust Design, Taguchi Method. \\
\hline Garvin & 1987 & 8 Dimensions of Product Quality. \\
\hline Joseph M. Juran & 1988 & $\begin{array}{l}\text { SPC (Statistical Process Control), Quality Planning, Quality Control, } \\
\text { Quality Improvement. }\end{array}$ \\
\hline $\begin{array}{l}\text { Zeithaml \& } \\
\text { Parasuraman }\end{array}$ & 1988 & 10 Dimensions of Service Quality. \\
\hline
\end{tabular}

During the implementation of TQM [24], there are 10 key elements that need to be developed [25], namely (1) a focus on the customer, (2) quality driven, (3) a scientific approach, (4) long-term commitment, (5) teamwork, (6) continuous system improvement, (7) education and training, (8) controlled freedom, (9) unity of purpose, and (10) involvement and empowerment of employees. Furthermore [26], there is a firm believes that there are four key principles in TQM, namely (1) customer satisfaction, (2) respect for the individual, (3) management based on facts, and (4) continuous improvement.

Further developments regarding quality management in companies around the world are finding some success and failure of TQM implementation mainly in America, Europe and even China and other parts of the world. TQM researchers and practioners thus have been actively looking for alternative solutions to create new 
theories or new methods to improve the quality of the results by using quality methods scuh as Six Sigma, ISO 9001, Lean System and MBNQA [27].

\subsection{Implementation of Total Quality Management}

The implementation of TQM [25] could be described in more detailed and systematic into three phases: the preparation phase, the planning phase and the implementation phase, as shown in Fig. 1.

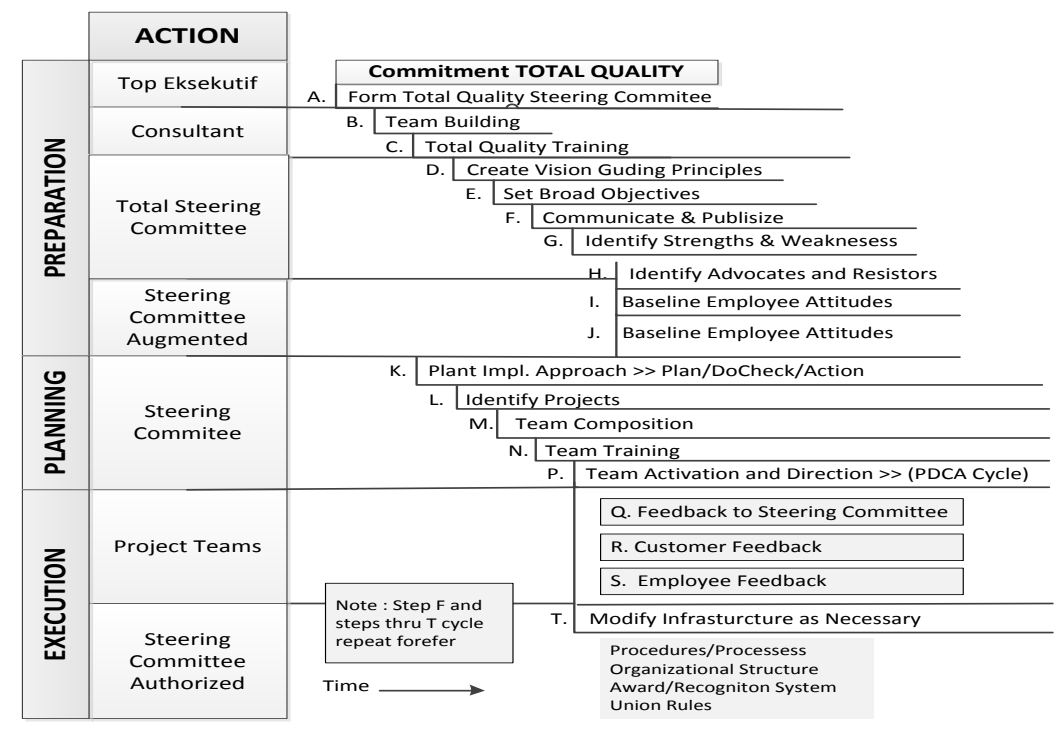

Figure 1. TQM Implementation Phase

TQM implementation involves essentially the beginning of the transformation of organizations operating in a new way, developing a new culture, and also involves the redesign of other systems. Consistent with a systems perspective, systems and resource allocation needs to be directed according to the TQM culture.

\subsection{Management and Performance}

Performance is an important variable in any organizational and job performance issues. There is an argumentation [28] that success in performing a task is determined by employee performance. In other words, performance is the decisive factor for success. In relation to organizational success, manager need to focus their attention on organizational in order to obtain an optimal results.

Research have shown that there are five types of competence [29]. First, knowledge of the individual in a particular field of work or area. Second, skill or the ability to exhibit physical or mental performance. Three, self-concept or individual attitudes and values that espoused self-image. Four, traits or physical characteristics that being consistent to the situation or information. Fifth, motives or thoughts or constant intentions that serve as a basis and encourage individuals to act or behave in a certain way. Skill and knowledge are often referred to as a hard competence, while the competence of self concept, traits and motives called soft competence.

Performance is a difficult concept to be understand, because its definition, measurement and construct is multidimensional. Therefore, performance measurement should be using or integrating diverse measurements dimensions (multiple measures). Furthermore there are two approaches used to assess the performance of the company [30], namely financial ratio analysis and stakeholder perspective view. To bring enlightment to this matter, there is a suggestion that the measurement of a multi-dimensional performance by means of investor performance indicators, customer performance indicators, supplier performance indicators, and government's internal performance indicators [31].

In line with previous research that have unearth the importance of organizational culture on organizational performance, current research threat organizational culture as intermediate variable (intervening variable). Organizational culture itself could be defined as a system of beliefs and values developed within an organization and directing the behavior of its members [32]. Furthermore, organizational culture means the pattern of organizational values, beliefs, and expectations that are embedded and developed among members of the organization about the job [33].

\subsection{Previous Research}

Previous research that have studied relation of TQM with culture and TQM with organizational performance are as follows: 
1. Similar studies have been carried out [34], that has conducted empirical studies on critical factors of TQM in Palestinian organizations. Conclusion of this study puts the top management commitment as the most important factor that determines the success of the implementation of TQM.

2. Other study [35] have also conducted a comprehensive analysis and developed frameworks from existing TQM literature that produced ten Critical Success Factor (CSFs) that determine the success of the implementation of TQM for construction companies. The results of this analysis also places top management commitment as the first priority.

3. There have been also a study on two groups of organizations in Libya [21]. The results concluded that the organization in Libya have diverse organizational background, and the dominant management style is 'power', while the preferred style is 'achievement'. Whereas in organization that have ISO current dominant management style is 'role', whereas the preferred style is 'achievement'. Industrial managers industry in Lybia embraces 'achievement' or 'support' as their management style is believed would support effective implementation of TQM.

4. Previous study [14] have compared the effects of cultural values on the successful implementation of TQM in Australia with Thailand. The results of these studies concluded that there is differences in organizational design models in Australia and Thailand on the success of TQM due to cultural differences. The study point to the fact that culture do have affects on what people think and behave. Substantial differences in both models was due the effect of centralization on the success of TQM were more pronounced in Australia than in Thailand. Whereas, the influence of formalization and real wage system were more pronounced in Thailand than in Australia.

5. In contrast to previous studies, the research that has been done [15] that included the variable of organizational performance as an indicator of the successful implementation of TQM, in addition to TQM variables and organizational culture. This study begins with an analysis on the factors of the TQM practices and organizational culture that yielded four dimensions of TQM and five cultural dimensions. The results of these studies concluded that customer focus and continuous improvement has the highest correlation coefficient to the overall performance. Both dimensions of TQM and cultural dimensions (human oriented) have a combined effect that contribute in lowering consumer complaints, improve reliability, and profitability. Meanwhile, customer focus and continuous improvement and its interactions with cultural dimensions (competitive ability) has contributions in increasing market share.

6. More comprehensive research has also been done [36], which relates the quality culture as an indicator of the successful implementation of TQM with unified communications practice. The results of these studies concluded that there is a positive interaction between the dominant culture 'clan', TQM principles, attitudes and communication behavior. In general, organizations prefer supportive communication climate. This is in contrary to the operational level as defensive communication climate is preferable as the employee was found to be more comfortable with hierarchy and formalization of the organization.

7. Research was also have been conducted [37, 38] to develop an instrument to measure TQM implementation in manufacturing industry in China. Zhang's study uses 11 indicators, namely the implementation of TQM Leadership, Supplier Quality, Management, Vision and Plan Statement, Evaluation, Control Process Improvement, Product Design, Quality System Improvement, Employee Participation, Recognition and Reward, Education and Training, and Customer focus. The results of this study indicate that these indicators was better than the same instruments used by previous investigators and was appropriate for China and other developing countries, especially for the manufacturing industry.

8. Research have also been conducted [39], which examines TQM and organizational culture. This research used TQM dimenstions such as Dominant Characteristic, Organizational Leadership, Management of Employees, Organizational Glue, Strategic Emphasis and Criteria of Success. In addition, this research also used dimensions of organizational culture that is Hierarchy Culture, Market Culture, Culture Clan, and Adhocracy Culture. The results of this study indicate that the successful implementation of TQM relies heavily on an understanding of the organizational environment, that is organizational culture. Organization would be better of and have capablity to be successful if they could implemented the values from the four types of culture within the organization.

9. Past research [40] have also examines the relationship between variable such as Committed Leadership, Adoption and Communication of TQM, Closer Customer Relationship, Closer Supplier Relationship, Benchmarking, Increased Training, Open Organizational Culture, Employee Empowerment, Zero-defect Mentality, Flexible Manufacturing, and Process Improvement Measurement. The results of this study showned that indicators such as Training Quality, Process Improvement and Benchmarking does not provide ample competitive advantage in general. On the other hand, indicators such as the Open Organizational Culture, Employee Empowerment, and Management Commitment can provide a competitive advantage. Implementation of TQM in manufacturing companies could bring better competitive advantage compared to those that implemented by service companies. Succesfull implementation of TQM could bring positive financial contribution to an organization. 


\section{Research Methodology}

Theoretical framework for this research is on analysing the implementation of TQM and its impact on organizational performance through the intervening variable organizational culture. Implementation of TQM in this study adopts instrument used in the past research [37,38]. As for variable organizational culture that being quality-oriented, this research using the measurement model from previous study [16]. Whereas, organizational performance variable is using the company's internal performance approach. Theoretical framework describes the research paradigm of thinking the relationship between independent variables of the implementation of TQM and intervening variables of organizational and their dependent variable of organizational performance in Fig. 2 below:

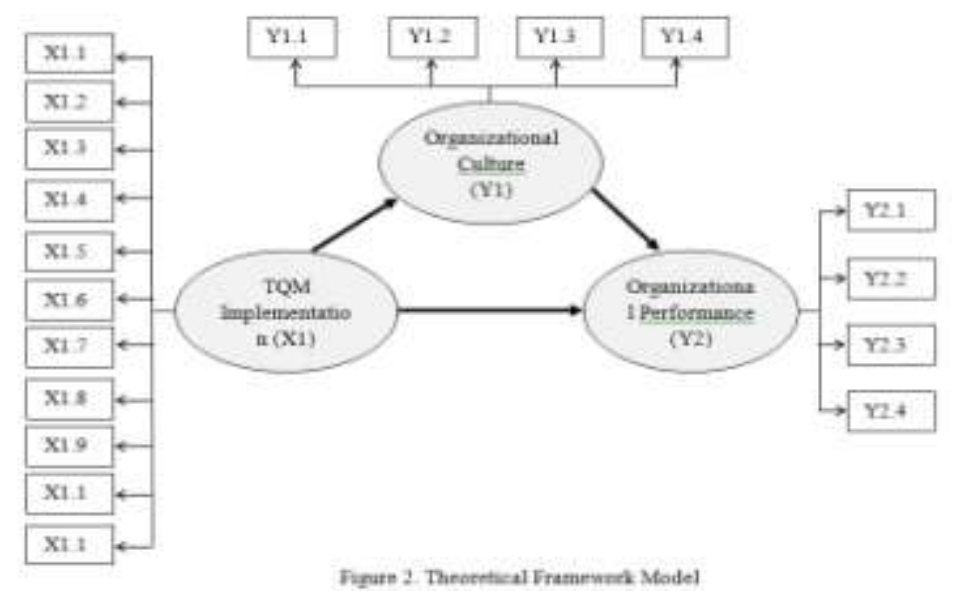

In Fig.2, TQM variable (X1) consists of 11 indicators that is $\mathrm{X} 1.1=$ Leadership, X1.2 = Supplier Quality Management, X1.3 = Vision and Plan Statement, X1.4 = Evaluation, x1.5 = Process Control Improvement, X1.6 = Product Design, x1.7 = Quality System Improvement, X1.8 = Employee Participation, X1.9 = Recognition and Reward, X1.10 = Education and Training and, X1.11 = Customer Focus. Variable Organizational Culture (Y1) that is quality-oriented is composed of four indicators, which is $\mathrm{Y} 1.1=$ Organizational Mission and Its Relationship to the Environment, Y1.2 = Nature of Organizational Goals and Facts, Y1.3 = Human Interaction, and Y1.4 = Nature of Time and Space. Variable Organizational Performance (Y2) is using the company's internal performance approach and they are Y3.1 = Financial Perspective, Y3.2 = Customer Perspective, Y3.3 = Internal Business Perspective, and Y3.4 = After-sales/Employee Capabilities Perspective.

\subsection{General Overview of Research Object}

\section{Result And Discussion}

The object of this study is large and medium-sized manufacturing industry in South Sulawesi that is based on data from Bureau of Central Statistics in South Sulawesi, which is found to be 301 company in 2010. Research population were all manufacturing companies that have implemented one variant of the integrated quality management within a minimum period of three years. Data collected by using a research instrument in the form of structured and unstructured questionnaire from the total of 456 respondents that holds the position as managers and ordinary employees. Sampel was randomly choosen and represents 21 major industries and 10 medium industries. The type and amount of manufacturing industry in South Sulawesi studied can be seen in Table 3 .

Table 3. Type and Number of Manufacturing Industry in South Sulawesi, Indonesia

\begin{tabular}{|c|l|c|c|}
\hline No & \multicolumn{1}{|c|}{ Industry Type } & Number of Company & Percentage \\
\hline 1 & Food and Beverage & 12 & 38.71 \\
\hline 2 & Cold Storage (Fish \& Shrimp) & 6 & 19.36 \\
\hline 3 & Lumber Processing & 3 & 9.68 \\
\hline 4 & Seaweed Processing & 3 & 9.68 \\
\hline 5 & Livestock Food & 3 & 9.68 \\
\hline 6 & Concrete & 1 & 3.23 \\
\hline 7 & Cement Industry & 2 & 6.46 \\
\hline 8 & Others Total & 1 & 3.23 \\
\hline \multicolumn{2}{|c|}{ Tor } \\
\hline
\end{tabular}

Based on Table 3, from eight type of the industry groups being studied, $38.71 \%$ come from the food and beverage industry, cold storage industry (19:36\%), lumber processing, seaweed processing and animal feed industry that respectively being $9.68 \%$, concrete industry $(3.23 \%)$, cement industry $(6.46 \%)$ and other industries 
Implementation of Total Quality Management and Its Effect on Organizational Performance of

(3.23\%). For purposes of analysis, respondents were managers, department heads and staff of each department in that understand about TQM or have sufficient understanding of the quality management systems.

Before distributing the questionnaire, we conducted interviews with managers in each company. Then, we proceed by distributing questionnaires to the respondents that being complemented with a follow-up interviews. In a period of approximately 3 months study, we visited each company periodically and checked the progress of each company by telephone.

\subsection{Analysis of Descriptive Statistics.}

The purpose of descriptive statistical analysis in this section is to interpret the average value of each indicator variable of this study and intended to provide an overview about the indicators being developed from the theoretical model. As a basic to interprete the average value of each indicators, we refers to the interpretation of scores as described in Table 4 below [41]:

Table 4. Item Scoring Interpretation Used in Research Variable

\begin{tabular}{|c|c|c|}
\hline No. & Scoring Value & Interpretation \\
\hline 1 & $1-1.8$ & Worst/not applicable \\
\hline 2 & $1.8-2.6$ & Less \\
\hline 3 & $2.6-3.4$ & Enough \\
\hline 4 & $3.4-4.2$ & Good/important \\
\hline 5 & $4.2-5.0$ & Very good/Very important \\
\hline
\end{tabular}

Description of the descriptive statistical analysis of each variable is described as follows. First, for the implementation of TQM variable (X1) that being measured by eleven indicators of TQM Implementation and described in Table 5. Table 5 is the recapitulation of the frequency distribution of respondents' answers to items from eleven indicators can be seen as follows:

Table 5. Frequency/Percentage Table on Indicator of the TQM Implementation

\begin{tabular}{|l|l|l|l|l|}
\hline TQM Implementation & Indicator Variable & Mean & Scoring Range & Interpretation \\
\hline Leadership & $\mathrm{X} 1.1$ & 4.16 & $3.4-4.2$ & Good/Important \\
\hline Supplier Quality Management & $\mathrm{X} 1.2$ & 4.07 & $3.4-4.2$ & Good/Important \\
\hline Vision and Plan Statement & $\mathrm{X} 1.3$ & 4.09 & $3.4-4.2$ & Good/Important \\
\hline Evaluation & $\mathrm{X} 1.4$ & 4.04 & $3.4-4.2$ & Good/Important \\
\hline Process Control Improvement & $\mathrm{X} 1.5$ & 4.04 & $3.4-4.2$ & Good/Important \\
\hline Product Design & $\mathrm{X} 1.6$ & 3.94 & $3.4-4.2$ & Good/Important \\
\hline Quality System Improvement & $\mathrm{X} 1.7$ & 4.28 & $4.2-5.0$ & Very Good / Very Important \\
\hline Employee Participation & $\mathrm{X} 1.8$ & 4.17 & $3.4-4.2$ & Good/Important \\
\hline Recognition and Reward & $\mathrm{X} 1.9$ & 3.82 & $3.4-4.2$ & Good/Important \\
\hline Education and Training & $\mathrm{X} 1.10$ & 4 & $3.4-4.2$ & Good/Important \\
\hline Customer Focus & $\mathrm{X} 1.11$ & 4 & $3.4-4.2$ & Good/Important \\
\hline
\end{tabular}

Second, for the variable of organizational culture (Y1) with four indicators, and a nine-item questionnaire that is (1) Organizational Mission and Its Relationship to Environment by item question: proactive enterprise and customer-dominated supply chain; (2) Nature of Organizational Goals and Facts with question items: the company has a real purpose and companies do continuous improvement; (3) Human Interactions; and (4) Nature of Time and Space. Respondents' perceptions of organizational culture can be seen in Table 6 below:

Tabel 6. Frequency/Percentage Table on Test Items of the Organizational Culture

\begin{tabular}{|c|c|c|c|c|c|c|c|c|c|c|c|}
\hline \multirow{3}{*}{$\begin{array}{c}\text { Organizational } \\
\text { Culture } \\
\text { Test Items }\end{array}$} & \multicolumn{10}{|c|}{ Skor Jawaban Responden } & \multirow[b]{3}{*}{ Mean } \\
\hline & \multicolumn{2}{|c|}{1} & \multicolumn{2}{|c|}{2} & \multicolumn{2}{|c|}{3} & \multicolumn{2}{|c|}{4} & \multicolumn{2}{|c|}{5} & \\
\hline & $\mathrm{F}$ & $\%$ & $\mathrm{~F}$ & $\%$ & $\mathrm{~F}$ & $\%$ & $\mathrm{~F}$ & $\%$ & $\mathrm{~F}$ & $\%$ & \\
\hline Y1.1.1 & 3 & 0.7 & 6 & 1.3 & 20 & 4.4 & 264 & 57.9 & 163 & 35.7 & 4.27 \\
\hline Y1.1.2 & 1 & 0.2 & 12 & 2.6 & 31 & 6.8 & 293 & 64.3 & 119 & 26.1 & 4.13 \\
\hline Y1.2.1 & 3 & 0.7 & 13 & 2.9 & 22 & 4.8 & 237 & 52.0 & 181 & 39.7 & 4.27 \\
\hline $\mathrm{Y} 1.2 .2$ & 1 & 0.2 & 16 & 3.5 & 34 & 7.5 & 262 & 57.5 & 143 & 31.4 & 4.16 \\
\hline $\mathrm{Y} 1.3 .1$ & 6 & 1.3 & 19 & 4.2 & 24 & 5.3 & 248 & 54.4 & 159 & 34.9 & 4.17 \\
\hline $\mathrm{Y} 1.3 .2$ & 2 & 0.4 & 57 & 12.5 & 120 & 26.3 & 213 & 46.7 & 64 & 14.0 & 3.61 \\
\hline Y1.3.3 & 4 & 0.9 & 6 & 1.3 & 39 & 8.6 & 215 & 47.1 & 192 & 42.1 & 4.28 \\
\hline Y1.4.1 & 2 & 0.4 & 6 & 1.3 & 31 & 6.8 & 224 & 49.1 & 193 & 42.3 & 4.32 \\
\hline Y1.4.2 & 2 & 0.4 & 10 & 2.2 & 28 & 6.1 & 274 & 60.1 & 142 & 31.1 & 4.19 \\
\hline \multicolumn{11}{|c|}{ Mean } & 4.15 \\
\hline
\end{tabular}

From Table 6, we could interpreted that respondents perceive organizational culture indicators as good/important. This is evident from the average value of 4.15 which suggests that organizational culture generally categorized as being good. This shows that the existing organizational culture of the company or 
Implementation of Total Quality Management and Its Effect on Organizational Performance of industry in South Sulawesi inhibits good organizational culture as indicated by company's mission related to the environment, culture that is based on goals and facts, and future-oriented culture. Herein organizational culture is the value system in an organization as the result of an environment that is conducive to the establishment of continuous quality improvement. Organizational culture itself consists of philosophy, beliefs, attitudes, norms, traditions, procedures, and expectations that can improve the quality.

Third, variable organizational performance with four indicators and twenty four items questionnaire that is (1) Financial Perspective with its question items: increased ROI, invest and reinvest, maximize assets and reduce costs. (2) Customer Perspective with its question items: increase new customers, number of customer complaints, and on-time customer service. (3) Internal Business Perspective that reflects the process of operating time with its question items: availability, reliability, production quality, the level of damage to the goods produced, reworking, production failures, wasted materials, processing time, and inspection time. (4) After-sales and Employees Capabilities Perspective with its question items: repair, consignment, credit collection, treatment of unpaid loans, spare-part readiness, successful use of new training techniques, hours of productive work, and generation of value-added. Respondents' perceptions about the organizational performance can be seen in Table 7.1 and Table 7.2 as follows:

Table 7.1 Frequency/Percentage Table on Test Items of the Organizational Performance (Financial and Customer Perspectives)

\begin{tabular}{|c|c|c|c|c|c|c|c|c|c|c|c|}
\hline \multirow{3}{*}{$\begin{array}{c}\text { Financial Perspective } \\
\text { Test Items }\end{array}$} & \multicolumn{10}{|c|}{ Respondent's Scoring Answer } & \multirow{3}{*}{ Mean } \\
\hline & \multicolumn{2}{|c|}{1} & \multicolumn{2}{|c|}{2} & \multicolumn{2}{|c|}{3} & \multicolumn{2}{|c|}{4} & \multicolumn{2}{|c|}{5} & \\
\hline & $\mathrm{F}$ & $\%$ & $\mathrm{~F}$ & $\%$ & $\mathrm{~F}$ & $\%$ & $\mathrm{~F}$ & $\%$ & $\mathrm{~F}$ & $\%$ & \\
\hline Y2.1.1 & 5 & 1.1 & 26 & 5.7 & 116 & 25.4 & 201 & 44.1 & 108 & 23.7 & 3.84 \\
\hline $\mathrm{Y} 2.1 .2$ & 4 & 0.9 & 5 & 1.1 & 60 & 13.2 & 274 & 60.1 & 113 & 24.8 & 4.07 \\
\hline Y2.1.3 & 0 & 0 & 10 & 2.2 & 70 & 15.4 & 273 & 59.9 & 103 & 22.6 & 4.03 \\
\hline $\mathrm{Y} 2.1 .4$ & 0 & 0 & 0 & 0 & 0 & 0 & 0 & 0 & 0 & 0 & 3.84 \\
\hline \multicolumn{11}{|c|}{ Mean } & 3.94 \\
\hline \multirow{3}{*}{$\begin{array}{c}\text { Customer Pespective } \\
\text { Test Items }\end{array}$} & \multicolumn{10}{|c|}{ Respondent's Scoring Answer } & \multirow[b]{3}{*}{ Mean } \\
\hline & \multicolumn{2}{|c|}{1} & \multicolumn{2}{|c|}{2} & \multicolumn{2}{|c|}{3} & \multicolumn{2}{|c|}{4} & \multicolumn{2}{|c|}{5} & \\
\hline & $\mathrm{F}$ & $\%$ & $\mathrm{~F}$ & $\%$ & $\mathrm{~F}$ & $\%$ & $\mathrm{~F}$ & $\%$ & $\mathrm{~F}$ & $\%$ & \\
\hline Y2.2.1 & 3 & 0.7 & 16 & 3.5 & 85 & 18.6 & 263 & 57.7 & 89 & 19.5 & 3.92 \\
\hline Y2.2.2 & 0 & 0 & 15 & 3.3 & 101 & 22.1 & 258 & 56.6 & 82 & 18.0 & 3.89 \\
\hline $\mathrm{Y} 2.2 .3$ & 2 & 0.4 & 6 & 1.3 & 46 & 10.1 & 306 & 67.1 & 96 & 21.1 & 4.07 \\
\hline \multicolumn{11}{|c|}{ Mean } & 3.96 \\
\hline
\end{tabular}

Table 7.2 Frequency/Percentage Table on Test Items of the Organizational Performance (Internal Business and After-sales/Employee Capabilities Perspectives)

\begin{tabular}{|c|c|c|c|c|c|c|c|c|c|c|c|}
\hline \multirow{3}{*}{$\begin{array}{c}\text { Internal Business } \\
\text { Perspective } \\
\text { Test Items }\end{array}$} & \multicolumn{10}{|c|}{ Respondent's Scoring Answer } & \multirow[b]{3}{*}{ Mean } \\
\hline & \multicolumn{2}{|c|}{1} & \multicolumn{2}{|r|}{2} & \multicolumn{2}{|c|}{3} & \multicolumn{2}{|c|}{4} & \multicolumn{2}{|c|}{5} & \\
\hline & $\mathrm{F}$ & $\%$ & $\mathrm{~F}$ & $\%$ & F & $\%$ & $\mathrm{~F}$ & $\%$ & $\mathrm{~F}$ & $\%$ & \\
\hline Y2.3.1 & 0 & 0 & 5 & 1.1 & 15 & 3.3 & 301 & 66.0 & 135 & 29.6 & 4.24 \\
\hline Y2.3.2 & 1 & 0.2 & 2 & 0.4 & 16 & 3.5 & 290 & 63.6 & 147 & 32.2 & 4.27 \\
\hline Y2.3.3 & 0 & 0 & 2 & 0.4 & 11 & 2.4 & 238 & 52.2 & 205 & 45.0 & 4.42 \\
\hline Y2.3.4 & 0 & 0 & 7 & 1.5 & 44 & 9.6 & 293 & 64.3 & 112 & 24.6 & 4.12 \\
\hline Y2.3.5 & 0 & 0 & 6 & 1.3 & 45 & 9.9 & 284 & 62.3 & 121 & 26.5 & 4.14 \\
\hline $\begin{array}{l}\text { Y2.3.6 } \\
\end{array}$ & 1 & 0.2 & 3 & 0.7 & 24 & 5.3 & 328 & 71.9 & 100 & 21.9 & 4.15 \\
\hline Y2.3.7 & 0 & 0 & 5 & 1.1 & 18 & 3.9 & 327 & 71.7 & 106 & 23.2 & 4.17 \\
\hline Y2.3.8 & 1 & 0.2 & 4 & 0.9 & 31 & 6.8 & 331 & 72.6 & 89 & 19.5 & 4.10 \\
\hline $\begin{array}{c}2.3 .9 \\
\end{array}$ & 1 & 0.2 & 3 & 0.7 & 18 & 3.9 & 345 & 75.7 & 89 & 19.5 & 4.14 \\
\hline \multicolumn{11}{|c|}{ Mean } & 4.19 \\
\hline \multirow{3}{*}{$\begin{array}{c}\text { After-sales/ } \\
\text { Employee } \\
\text { Capabilities Test } \\
\text { Items }\end{array}$} & \multicolumn{10}{|c|}{ Respondent's Scoring Answer } & \multirow[b]{3}{*}{ Mean } \\
\hline & \multicolumn{2}{|c|}{1} & \multicolumn{2}{|c|}{2} & \multicolumn{2}{|c|}{3} & \multicolumn{2}{|c|}{4} & \multicolumn{2}{|c|}{5} & \\
\hline & $\mathrm{F}$ & $\%$ & $\mathrm{~F}$ & $\%$ & $\mathrm{~F}$ & $\%$ & $\mathrm{~F}$ & $\%$ & $\mathrm{~F}$ & $\%$ & \\
\hline Y2.4.1 & 0 & 0 & 5 & 1.1 & 27 & 5.9 & 314 & 68.9 & 110 & 24.1 & 4.16 \\
\hline Y2.4.2 & 0 & 0 & 2 & 0.4 & 24 & 5.3 & 362 & 79.4 & 68 & 14.9 & 4.09 \\
\hline Y2.4.3 & 1 & 0.2 & 2 & 0.4 & 42 & 9.2 & 331 & 72.6 & 80 & 17.5 & 4.07 \\
\hline Y2.4.4 & 1 & 0.2 & 1 & 0.2 & 35 & 7.7 & 335 & 73.5 & 84 & 18.4 & 4.10 \\
\hline Y2.4.5 & 0 & 0 & 2 & 0.4 & 50 & 11.0 & 315 & 69.1 & 89 & 19.5 & 4.08 \\
\hline Y2.4.6 & 4 & 0.9 & 4 & 0.9 & 58 & 12.7 & 300 & 65.8 & 90 & 19.7 & 4.03 \\
\hline Y2.4.7 & 0 & 0 & 3 & 0.7 & 44 & 9.6 & 287 & 62.9 & 122 & 26.8 & 4.16 \\
\hline Y2.4.8 & 0 & 0 & 4 & 0.9 & 40 & 8.8 & 289 & 63.4 & 123 & 27.0 & 4.16 \\
\hline \multicolumn{11}{|c|}{ Mean } & 4.11 \\
\hline
\end{tabular}


From Table 7.1 it can be seen that perceptions of respondents towards Financial Perspective indicators have a good value. This is evident from the average value of 3.94, which indicates the importance of overall financial performance. This shows that the company/industry in South Sulawesi has a good financial performance as seen from the increase in ROI from year to year.

On the indicators on Customer Perspective from Table 7.1, could be seen that the respondents gave a good value. It is apparent from the average value of 3.96 that indicates that the overall customer performance is important. This shows that the company/industry in South Sulawesi has a good customer performance as they strive to attract the number of new customers, by reducing the number of customer complaints and on-time in accomodating the needs of their existing consumers.

On the indicators on Internal Business Perspective in Table 7.2, it is apparent that respondents gave a good value. This is evident from the average value of 4.19 , which shows that the overall performance of organizational internal operation is important. This shows that the company/industry that reside in South Sulawesi has a good performance in maintaing their operation as indicated by the availability, reliability, production quality, the level of damage to goods in production, rework, production failures, wasted materials, processing time, and inspection time in the process of operation.

From Table 7.2 on the indicators for After-sales/Employee Capabilities Perspective, respondents gave a good value. This is evident from the average value of 4.11, which indicates the importance of overall after-sales performance and employee capabilities as shown through repair, consignment, credit collection, treatment of unpaid loans, spare-parts readiness, successful use of new training techniques, hours of productive work, and generation of value added.

\subsection{Analysis of Research}

Analysis of the results of research is conducted by using Structural Equation Model (SEM) and Confirmatory Factor Analysis (CFA) with the help from AMOS 18.0 program tool [42]. The predictive power of observation variables at both the individual and at the level of the construct could be seen through the critical ratio (CR). If the $\mathrm{CR}$ is significant, then the dimensions will be useful for predicting the aforementioned constructs or latent variables. Latent variable (construct) in this study consisted of TQM implementation, organizational culture, and organizational performance.

Several criteria then being used to test whether the proposed model has the compatibility with the data or not. The model fit criteria state that (1) degrees of freedom (DF) must be positive, (2) the requirement for non-significant Chi-square which is $p \geq 0.05$, while for a large sample $(\mathrm{N}>250)$ the significance of $p$ - value can not be expected, (3) incremental fit value must be above 0.90 either in the form of GFI (Goodness of Fit Index), Adjusted GFI (AGFI), Tucker Lewis Index (TLI), Minimum Sample Discrepancy Function (C min) divided by DF and the Comparative Fit Index (CFI), and (4) RMSEA (Root Mean Square Error of Aproximation) is low [43].

Confimatory Factor Analysis (CFA) is used to examine the variables that define a construct that can not be measured directly. Analysis of the indicators that are used to give the meaning of the label was given to the latent variables or constructs that being confirmed.

\subsubsection{Evaluation Criteria for Goodness-of-Fit}

Evaluation of the accuracy of the model has essentially done at the model estimated by AMOS. A complete pre-evaluation of this model are conducted by testing the normality assumption and evaluating their outliers.

Univariate and multivariate normality of the data used in this analysis, tested using AMOS 18. Critical size for testing normality is by means of calculating its CR calculation that affected by its sample size and skewness. With reference to the value of CR, then if the column contained CR score is greater than 2.58 or smaller than -2.58 (normal distribution of the alpha is 1 percent), then we could conclude that there is evidence that the distribution of the data is not normal. In opposite, when the value of CR is less than 2.58 or more greater than -2.58 , then the data were normally distributed. Using the above criteria, it can be concluded that from 25 indicators in this study, 23 indicators are not normally distributed, as their CR value is greater than 2.58 , whereas the remaining two indicators were normally distributed.

Besides that, evaluation of the outliers in this study consists of two parts, namely the evaluation of univariate and multivariate outliers. First, dealing with univariate outliers, then on the basis that the cases or observations have a $\mathrm{z}$-score $=3.0$ will be categorized as outliers. And for a large sample of over 80 observation, evaluation guidelines suggested that the threshold value of the z-score is in the range of 3 to 4 [44, 45]. As this study can be categorized as research with a large sample of 456 respondents, which means far above 80 observations, then the outliers occur if the $\mathrm{z}$-score $=4.0$. Based on the descriptive statistics table that all values in the form of standardized z-score has an average equal to zero with a standard deviation of one, as theorized [46]. From the results of the computations, we note that the data used in this study were free of univariate 
Implementation of Total Quality Management and Its Effect on Organizational Performance of outliers, because no variables that have a z-score above the limit as the minimum z-score $=-4.81131$ (z-score from Employee Participation) and the maximum z-score $=3.97579$ ( $z$-score from Vision and Plan Statement).

Second in dealing with multivariate outliers, the determination whether a case (form various answers of a respondent) raises multivariate outlier, is calculate by means of the limit values that based on the value of Chisquare on DF for the number of variables at a significance level of 0.001 or $\chi^{2}(29 ; 0.001)$. Multivariate outliers cases occurs if the value of Mahalanobis Distance is greater than the value of Chi-square count [45]. Based on the Chi-square value on $\mathrm{DF}=29$ (number of variables) at a significance rate of 0.001 or significant $\chi 2(29 ; 0.001)$ $=58.3012[47,48]$. It appears from the results of calculations using values obtained from AMOS that the minimum value of Mahalanobis Distance-squared is 33.283 and the maximum value is 183.811 . Thus, we could concluded that there is an existences of multivariate on the fifteenth observations, but basically outliers can not be removed if the data outliers describes the condition of the data (no error in imput data).

\subsubsection{Measurement Results on Constructs or Latent Variables}

After testing the assumptions and necessary action against violations that occurred, subsequent analysis will be continued with the model fit as suggested. In this section, the model fit criteria being employed are GFI (Goodness of Fit Index), adjusted GFI (AGFI), Tucker Lewis Index (TLI), CFI (Comparative Fit Index of) and RMSEA (Root Mean Square Error of Approximation) for individual models as well as overall models. The results of measurements of the dimensions or indicators of variables that can form a construct or latent variable with Confirmatory Factor Analysis respectively described in the following paragraphs.

The test results of TQM implementation constructs variables were evaluated by Goodness of Fit Indices in Table 8 along with the presented criteria as well as the model of the critical value. From the evaluation of the proposed model, this table shows the evaluation of the overall construct that generate the critical value that is above the cut-off value $[42,43]$. This would indicates whether the model was fit to the data and suitable to be tested.

Table 8. Evaluation of the Goodness of Fit Criterion on TQM Implementation

\begin{tabular}{|c|c|c|c|}
\hline Goodness of fit index & Cut-off Value & Model Result & Note \\
\hline$\chi^{2}-$ Chi-square & Small is expected & $123.147>(0.05 ; 39=54.5722)$ & Marginal \\
\hline Probability & $\geq 0.05$ & 0.001 & Marginal \\
\hline CMIN/DF & $\leq 2.00$ & 3.158 & Marginal \\
\hline RMSEA & $\leq 0.08$ & 0.069 & Good \\
\hline GFI & $\geq 0.90$ & 0.953 & Good \\
\hline AGFI & $\geq 0.90$ & 0.920 & Good \\
\hline CFI & $\geq 0.92$ & 0.978 & Good \\
\hline TLI & $\geq 0.92$ & 0.969 & Good \\
\hline
\end{tabular}

Table 8 shows that the measurement model of TQM implementation model suits the criteria being used to test the model fit. It is evident from the existing eight fixed criteria, there were five that meet the criteria. Thus refers to the principle of parsimony in the theory, then the model shows a good level of acceptance. Therefore, we could concluded that the model is acceptable.

Furthermore, the determination of the variables that can be used as an indicator of TQM Implementation could be observed from the loading factor or coefficient value of lambda $(\lambda)$ and the level of significance that reflecting each variable as an indicator of TQM implementation as shown in table 9.

Tabel 9. Loading Factor $(\lambda)$ Measurement of the TQM Implementation Factor

\begin{tabular}{|l|c|c|c|c|}
\hline Indicator Variabel & Loading Factor $(\lambda)$ & Critical Ratio & Probability $(\mathrm{p})$ & Notes \\
\hline X1.1 & 0.692 & 15.318 & $<0.001$ & Significant \\
\hline X1.2 & 0.781 & 17.638 & $<0.001$ & Significant \\
\hline X1.3 & 0.741 & 16.575 & $<0.001$ & Significant \\
\hline X1.4 & 0.882 & 20.422 & $<0.001$ & Significant \\
\hline X1.5 & 0.785 & 15.686 & $<0.001$ & Significant \\
\hline X1.6 & 0.760 & 17.092 & $<0.001$ & Significant \\
\hline X1.7 & 0.830 & 18.951 & $<0.001$ & Significant \\
\hline X1.8 & 0.843 & 19.337 & $<0.001$ & Significant \\
\hline X1.9 & 0.764 & Fix & $<0.001$ & Significant \\
\hline X1.10 & 0.747 & 22.056 & $<0.001$ & Significant \\
\hline X1.11 & 0.721 & 16.042 & $<0.001$ & Significant \\
\hline
\end{tabular}

Loading factor $(\lambda)$ of the measurement variable of TQM implementation in Table 9 shows the results of testing of the measurement model of TQM implementation variables describing each indicator constructs, 
Implementation of Total Quality Management and Its Effect on Organizational Performance of particularly the latent variables (unobserved variable). The result shown that all the indicators could be included in the next test.

Table 10 presented the criteria being used to test the model and the value of the critical criteria for the the organizational culture variable. From the evaluation of the proposed model, this table shows the evaluation of the overall construct that generate the critical value that is above the cut-off value. This would give an indication whether or not the model was fit to the data and suitable to be tested.

Tabel 10. Evaluation of the Goodness of Fit Criterion on Organizational Culture

\begin{tabular}{|c|c|c|c|}
\hline Goodness of fit index & Cut -off Value* & Model Result & Note \\
\hline$\chi^{2}-$ Chi-square & Small is expected & $7,459>(0,05: 1=3,8414)$ & Marginal \\
\hline Probability & $\geq 0.05$ & 0.006 & Marginal \\
\hline CMIN/DF & $\leq 2.00$ & 7,459 & Not Good \\
\hline RMSEA & $\leq 0.08$ & 0.119 & Not Good \\
\hline GFI & $\geq 0.90$ & 0.992 & Good \\
\hline AGFI & $\geq 0.90$ & 0.919 & Good \\
\hline CFI & $\geq 0.92$ & 0.990 & Good \\
\hline TLI & $\geq 0.92$ & 0.941 & Good \\
\hline
\end{tabular}

Table 10 shows that the measurement model of organizational culture suits the criteria being used to test the model fit. It is evident from the existing eight fixed criteria, there are four that have met the criteria. Thus refers to the principle of parsimony in the theory, the model showed a good acceptance rate and the model is acceptable.

Furthermore, the determination of the variables that can be used as an indicator of organizational culture could be observed from the loading factor or coefficient value of lambda $(\lambda)$ and the level of significance that reflecting each variable as an indicator of organizational culture as shown in Table 11.

Tabel 11. Loading Factor $(\lambda)$ Measurement of the Organizational Culture Factor

\begin{tabular}{|l|c|c|c|c|}
\hline Indicator Variabel & Loading Factor $(\lambda)$ & Critical Ratio & Probability $(\mathrm{p})$ & Note \\
\hline Y1.1 & 0.729 & 14.613 & $<0.001$ & Significant \\
\hline Y1.2 & 0.796 & Fix & $<0.001$ & Significant \\
\hline Y1.3 & 0.632 & 12.466 & $<0.001$ & Significant \\
\hline Y1.4 & 0.805 & 16.957 & $<0.001$ & Significant \\
\hline
\end{tabular}

Loading factor $(\lambda)$ measurement of organizational culture variables in Table 11 shows the test results of the measurement model of organizational cultural variables describing each indicator constructs, particularly the latent variables (unobserved variable). The result shown that all the indicators could be included in the next test. CFA test results also shown the overall organizational performance variable model that consisting of a variable construct. Test results that being evaluated based on organizational performance in Table 12 below with the model presented criteria as well as the critical value. From the evaluation of the proposed model, we could then shows whether the evaluation of the overall construct generate the critical value above the cut-off value, and suitable to be tested further in model.

Tabel 12. Evaluation of the Goodness of Fit Criterion on Organizational Performance

\begin{tabular}{|c|c|c|c|}
\hline Goodness of Fit Index & Cut-off Value & Model Result & Note \\
\hline$\chi^{2}-$ Chi-square & Small is expected & $0.404<(0.05: 1=3.814)$ & Good \\
\hline Sign.Probability & $\geq 0.05$ & 0.525 & Good \\
\hline CMIN/DF & $\leq 2.00$ & 0.404 & Good \\
\hline RMSEA & $\leq 0.08$ & 0.000 & Good \\
\hline GFI & $\geq 0.90$ & 1.000 & Good \\
\hline AGFI & $\geq 0.90$ & 0.996 & Good \\
\hline TLI & $\geq 0.92$ & 1.000 & Good \\
\hline CFI & $\geq 0.92$ & 1.000 & Good \\
\hline
\end{tabular}

Table 12 shows the organizational performance measurement model, and that the model has demonstrated the criteria of model fit or fit between the data model. It is evident from the existing eight fixed criteria fix that all meet the criteria. Thus, the above model shows a good level of acceptance and can therefore be concluded that the model is acceptable. 
Furthermore, to determine the variables that can be used as an indicator of organizational performance can be observed from the value of loading factor or coefficient lambda $(\lambda)$ and the level of significance, reflecting each variable as an indicator of performance shown in table 13.

Tabel 13. Loading Factor $(\lambda)$ Measurement of the Company Performance Factor

\begin{tabular}{|l|c|c|c|c|}
\hline Indicator Variable & Loading Factor $(\lambda)$ & Critical Ratio & Probability $(\mathrm{p})$ & Note \\
\hline Y2.1 & 0.804 & 13.668 & $<0.001$ & Significant \\
\hline Y2.2 & 0.820 & Fix & $<0.001$ & Significant \\
\hline Y2.3 & 0.618 & 11.969 & $<0.001$ & Significant \\
\hline Y2.4 & 0.578 & 11.166 & $<0.001$ & Significant \\
\hline
\end{tabular}

Loading factor $(\lambda)$ measurement of performance variables in Table 13 shows the test results of the measurement model of organizational performance variables describing each indicator constructs, particularly the latent variables (unobserved variable). The result shown that all the indicators could be included in the next test.

Finally, the overall model would be believed to be good statistically if the hypothetical model development is theoretically supported by empirical data. SEM analysis on the complete model results that being evaluated by GFI is shown in Table 14 below. This table presented the cut-off criteria (critical values) that have compliance to the data being used.

Table 14. Evaluation of the Goodness of Fit Indices on Overall Model

\begin{tabular}{|c|c|c|c|}
\hline Goodness of Fit Index & Cut-off Value & Model Result & Note \\
\hline$\chi^{2}-$ Chi-square & Small is expected & $808.892>(0.05 ; 253=291.102)$ & Marginal \\
\hline Probability & $\geq 0.05$ & 0.000 & Marginal \\
\hline CMIN/DF & $\leq 2.00$ & 3.197 & Not Good \\
\hline RMSEA & $\leq 0.08$ & 0.069 & Good \\
\hline GFI & $\geq 0.90$ & 0.871 & Not Good \\
\hline AGFI & $\geq 0.90$ & 0.835 & Not Good \\
\hline TLI & $\geq 0.92$ & 0.936 & Good \\
\hline CFI & $\geq 0.92$ & 0.925 & Good \\
\hline
\end{tabular}

Evaluation of the model in Table 14 shows that from the eight criteria of GFI, there were three criteria that is due to a very large sample, which have the value of 456 that made the probability can not be calculated [43]. Apart from this, the GFI and AGFI values already approaching the critical value, so the model as a whole can be said to have been in accordance with the data and can be analyzed further.

\subsection{Hypothesis Testing}

Based on empirical models proposed in this study, we could then further tested the hypothesis by using the path coefficients in SEM. Table 15 is a test of the hypothesis by looking at the $p$ value. If the $p$ value is less than 0.05 then there is an existance of relationship between the significant variables. The test results are presented in the following table.

Table 15. Hypothesis Testing

\begin{tabular}{|c|c|c|c|c|c|c|}
\hline \multicolumn{7}{|c|}{ Direct Effect } \\
\hline Hypothesis & Independent Variable & Dependent Variable & Std. & $\mathrm{CR}$ & $p$-value & Note \\
\hline H1 & TQM Implementation & $\begin{array}{l}\text { Organizational } \\
\text { Culture }\end{array}$ & 0.884 & 17.522 & 0.000 & Significant \\
\hline $\mathrm{H} 3$ & TQM Implementation & $\begin{array}{l}\text { Organizational } \\
\text { Performance }\end{array}$ & -0.311 & -1.336 & 0.181 & $\begin{array}{c}\text { Not } \\
\text { Significant }\end{array}$ \\
\hline $\mathrm{H} 4$ & $\begin{array}{l}\text { Organizational } \\
\text { Culture }\end{array}$ & $\begin{array}{l}\text { Organizational } \\
\text { Performance }\end{array}$ & 0.513 & 4.919 & 0.000 & Significant \\
\hline \multicolumn{7}{|c|}{ Indirect Effect } \\
\hline Hypothesis & Independent Variable & Dependent Variable & \multicolumn{2}{|c|}{ Intervening Variable } & Std. & Note \\
\hline $\mathrm{H} 3$ & TQM Implementation & $\begin{array}{l}\text { Organizational } \\
\text { Performance }\end{array}$ & \multicolumn{2}{|c|}{$\begin{array}{l}\text { Organizational } \\
\text { Culture }\end{array}$} & 0.453 & Significant \\
\hline
\end{tabular}

On the overall model, we could claimed that there are three direct relationship, where two paths are significant paths and one were not significant. The paths also showed significant indirect relationship. The interpretation of Table 15 can be explained as follows: 
Implementation of Total Quality Management and Its Effect on Organizational Performance of

1. TQM implementation has a significant positive effect on organizational culture with $\mathrm{p}=0.000<0.05$ and a coefficient of 0.884 . This coefficient indicates that the presence of the better implementation of TQM in a company, would foster better organizational culture.

2. TQM implementation has no significant effect on the performance of companies with $p=0.181>0.05$ and a negative coefficient of -0.311 . This means that the implementation of TQM are not having direct relationship to improve organizational performance. This condition explains that when TQM practices implemented without preparing organizational resources, then this effort will not improve organizational performance. Furthermore, there is a greater possibility that TQM implementation would decline.

3. Organizational culture has a significant influence on organizational performance as $p=0.000<0.05$ with a coefficient of 0.513 . This coefficient indicates that the more conducive the culture within a company, then there is greater probability that the company's performance will increase.

4. The indirect effect of TQM implementation on organizational performance through organizational culture has a positive and significant value with $\mathrm{p}=0.000<0.05$ and a coefficient of 0.453 . This coefficient shows that as implementation of TQM within a company is increased, then the culture of the organization will be better.

Table 15 also shows that there is a significant effect of line and not significant and we could state that the following hypothesis, which is $\mathrm{H} 1$ : Implementation of TQM have an influence on organizational culture; $\mathrm{H} 2$ : Organizational culture has an influence on the organizational performance, and H3: Implementation of TQM have any impact on organizational performance through organizational culture supported by empirical data and received. As for hypothesis H4: The implementation of TQM have any impact on organizational performance is not supported by empirical data and is rejected.

\subsection{Discussion}

This discussion focused on the decisions resulting from hypothesis testing in an attempt to answer the formulation of research problems. First, the discussion on the results of the analysis of hypothesis testing is relating to the effect of TQM implementation on organizational culture. The test results showed that the implementation of TQM has positive and significant effect on organizational culture in the industry in South Sulawesi, Indonesia. This finding is consistent with previous research [39], which showed that the TQM implementation success depends on an understanding of the organization, particularly organizational culture to ensure that organization would be capable of carrying out one of the four types of cultural values within the organization.

TQM implementation relationships with organizational culture has been described in previous research [49]. Thus, it is argued that implementation of the principles of TQM would create organizational climate that would be conducive to the realization of quality culture, which would then have a trickle down effect to change the code of conduct of organizational members. This change of conduct must be accompanied by overall systems overhaul and strong leadership that have a preferences toward quality. In the long run, the employees who have been educated and empowered will eventually embraces quality as one their code of conduct and began to develop good work habits. Good employee code of conduct needs to be internalized and maintained by making the work environment supportive to employee's quality efforts. This internationalization process that is conductive to quality would put everyone within an organization embrace quality as part of their attitude or code of conduct and would be internalized and strengthened over time through quality leadership as the system within an organization improves.

One common reason for the failure of TQM is a culture that is inhibited by the company [50]. Past research [51] also states that cultural change and behavioural change management as a key factor in the successful implementation of TQM. TQM performance is determined by the change in organizational culture [52], in addition to other factors such as the expenses of money and time, the transformation of traditional management practices, and a strong desire to endure short-term losses for long-term profitability. Previous research [18] also have clarified the above ideas by stating that TQM is a transformational change. The implementation of TQM requires a shared mindset that emphasizes customer satisfaction, shared leadership, and getting it right first time. So in their view TQM can be effective, but can also be ineffective. Its effectiveness is determined by whether or not a company developed a culture of quality. When a quality culture in the organization successfully grown, it maximises the probability of success, and vice versa.

Without a change in culture, especially the culture of quality, it is difficult to expect TQM program will experience success. It thus becomes an urgent problem to establish cultural understanding and measurement of acceptable quality by organizational members and how cultural change can be done effectively. Understanding on the culture of quality and management issues are still limited and further research is needed to triggering the need for more rigorous future research related to this one.

Second, is on the effect of organizational culture on organizational performance. The results show that organizational culture has positive and significant impact on organizational performance within an inudstry in South Sulawesi, Indonesia. This finding is consistent with past research [15] that concluded customer focus and 
Implementation of Total Quality Management and Its Effect on Organizational Performance of

continuous improvement has the highest correlation coefficient to the overall performance. Both dimensions of TQM and cultural dimensions (human orientation) has combination effect and would have contributed to lower consumer complaints, improve reliability, and profitability. Meanwhile, customer focus and continuous improvement and its interactions with cultural dimensions (competitive ability) has contributions in increasing market share.

Moreover, to generate an organizational culture that is conducive to continuous improvement where everyone can participate, there arise a need to interface the quality assurance into all the processes and functions of the organization. Organization need to triggered changes in people's behavior, mental attitude, and work practices in a variety of ways. Changing behavior and mental attitude is one of the most difficult management task, requiring great strength and persuasive skills and motivation. Management commitment is also required to facilitate and manage the cultural change towards a culture of quality. Indirectly this is in tune with the culture of quality [25] that stated a need of organizational value system that produces an environment that is conducive to the establishment of continuous quality improvement.

Third, is on the indirect effect of TQM implementation on organizational performance through organizational culture. The test results showed that the implementation of TQM on organizational performance through organizational culture has positive and significant effect at industry in South Sulawesi, Indonesia. This finding is in line with previous research [39], which showed that the success of TQM implementation very much depends on an understanding of the organization, especially organizational culture.

Deeper understanding on organizational culture becoming more important as TQM requires a paradigm shift in conducting business, company must build a new corporate culture. Management commitment in this regard becomes a must in order to make changes so that transformation of company culture to the culture of quality through application of TQM can be run successfully. In organizations that implement TQM, training and education is a fundamental factor. Proper training and education to each employee is become a must in order to improve their skills and expertise.

And finally, on the effect of TQM implementation on organizational performance. The test results showed that the implementation of TQM have no significant effect on organizational performance of the industry in South Sulawesi, Indonesia. This finding is not consistent with past research [53], which indicates that there is a significant positive relationship between organizational performance and four other independent variables. TQM implementation success is determined by the support of organizations and good relationships between employees (co-workers). Need an effort to integrate human resource management with TQM. TQM implementation thoroughly and comprehensively better than pick just a few items.

However, the test results in this study is in line with other research [54] that showed the certification of ISO 9000 does not show a significant positive effect on organizational performance. Also no difference in performance between the organizations that implement TQM by companies that do not implement TQM. This supports the view that the ISO 9000 certification has little effect or are less able to explain the strength of the organization's performance. In contrast, different results could be found in past research [55] that implicitly states that companies that adopt formal TQM program in practice is superior to those firm who do not implement TQM program. The findings also indicate a strong influence between TQM practices and quality performance, but there was no significant difference in quality performance between organizations that implement TQM program formally with organizations adopting TQM practices in non-formal. This suggests that the adoption of quality practice is even more important than the formal program.

\section{Conclusion}

In conclusion, implementation of TQM in the number of companies manufacturing industry in South Sulawesi have a positive and significant influence in shaping the organizational culture of the company. TQM requires insight and knowledge of more advanced technology, attitudes and behavior as a discipline in every process demands the application of science, technology and art. The findings confirmed the acceptances of two hypotheses that test the influence of organizational culture on organizational performance. Positive and significant results obtained showed that the manufacturing industry employees in South Sulawesi firms perceived cultural factors in the implementation of TQM as a factor driving the performance of the company.

Hypothesis three revealed the indirect effect of the implementation of TQM on organizational performance through organizational culture variables. Research results from this study are consistent with the our previous assumption that the implementation of TQM have an indirect effect on organizational performance. This finding also supports previous assumption that the general manufacturing industry employees in South Sulawesi saw the implementation of TQM intersect closely with the developement and formation of the cultural ethos of hard work that in turn will affect the performance of the company.

Hypothesis four unearth that there is no direct influence between the implementation of TQM on organizational performance. This provide deeper information on understanding company's employees at various levels of management that the implementation of TQM is a continuous effort and should be seen as a long process and is not necessarily directly affect the performance of the company. 
Finally, the application of exploratory models developed from the early models have consistently continued to support previous findings that TQM implementation has no significant direct impact on organizational performance. However, the implementation of TQM have indirect positive and significant impact on firm performance through organizational culture variables.

Furthermore, based on the analysis and findings of the study, we could put forward several suggestions related to the management of the manufacturing industry in South Sulawesi, Indonesia. First, improved performance can not be done in the short term, but it must be done through continuous efforts to build a culture of quality in a sustainable commitment from all employees. Leaders need to embrace the concept of strategic leadership in manufacturing in order to improve the dissemination program on a shared vision, alignment mindset, and the need to develop units of work in a variety of quality control group.

Second, the manufacturing industry in South Sulawesi, Indonesia need to change the paradigm of management processes in order to more effectively implement TQM and impact company performance. TQM requires knowledge-based management and therefore competing strategies need to be aligned by means of knowledge acquisition and the application of cutting-edge technology that is in line with the term knowledge mangement (KM). KM stressed the need for an employee and manager to have access to the flow of information (knowledge flow), knowledge sharing and development of task forces that gave birth to wisdom in performing their work in the form of tacit knowledge.

Third, in this era of globalization, which is full of fierce competition, companies must be able to demonstrate its ability to meet market demands. The success in winning the competition is not only determined by the ability to manage and improve the company's resources, but also determine by the quality as the key factor that plays a very important part to achieve excellence. Moreover quality, nowadays, become the most reliable factor that a company must achieve to continue to fulfill consumer satisfaction.

\section{References}

[1] http://www.fajar.co.id/read-20110113113814-angsa-terbang-menuju-china

[2] http://www.worldbank.co.id

[3] Biro Pusat Statistik, Statistik Industri Besar dan Sedang Provinsi Sulawesi Selatan (Indonesia, 2010).

[4] Biro Pusat Statistik, Indikator Industri Besar dan Sedang Provinsi Sulawesi Selatan (Indonesia, 2011).

[5] M.A. Hitt et al, Applications of structural equation modeling in marketing and consumer research: A review. International Journal of Research in Marketing, 13, 1997, 139-161.

[6] Biro Pusat Statistik, Produk Domestik Regional Bruto Provinsi Sulawesi Selatan (Indonesia, 2010).

[7] M.K. Muluk, Manajemen Pengetahuan: Kebingungan Praktek dan Peta Kajian, Usahawan, 32(4), April 2003.

[8] V. Gaspersz, Total Quality Management (Jakarta, Indonesia: Gramedia Pustaka Utama, 2005).

[9] P. Boselie and T.V.d. Wiele, Employee perceptions of HRM and TQM and The Effects on Satisfaction and Intention to Leave, Journal of Operations Management 18(5), 2001, 549-575.

[10] Huarng and Yao, Relationships of TQM Philosophy, Methods and Performanve: a Survey in Taiwan, (2002).

[11] Laily, Sikap Manajer Menengah Terhadap Penerapan Total Qualty Management (TQM) dan Pengaruhnya Terhadap Kinerja Manajerial (2003).

[12] A.R. Sularso and Murdijanto, Pengaruh Penerapan Peran Total Quality Management Terhadap Kualitas Sumberdaya Manusia (2004).

[13] Kekale, Total quality management in an R\&D environment. International Journal of Operations and Productions Management, 17 (2), 1999, 184-198.

[14] Parncharoen, Girardi, dan Entrekin, The Impact Cultural Values on the Successful Implementation of Total Quality Management: A Comparison between the Australian and Thai Models (2005), 597.

[15] Jabnoun and Sedrani, TQM, Culture, and Performance in UAE Manufacturing Firms, Journal of Quality Management, 1(1), 2005, 67-89.

[16] Kujala and Ullarank, Cultural theory and contemporary management organization. Human Relations 52(5), 2004, 557-577.

[17] K.B. Hendricks and V.R. Singhal, The impact of total quality management (TQM) on financial performance; Evidence from quality award winners. Retrieved February 5, 2000: http://www.efqm.org/new_website/model_awards/downloads/keyabstract.pdf

[18] M. Abraham, J. Crawford, and T. Fisher, Key factors predicting effectiveness of cultural change and improved productivity in implementing total quality management, International Journal of Quality \& Reliability Management, 16(2), 1999, $112-132$.

[19] D. Adebanjo and D. Kehoe, An investigation of quality culture development in UK industries, International Journal of Operation \& Production Management, 19(7), 1999, 633-649.

[20] Gore, Organizational Culture, TQM, and Business Process Reengineering, European Journal of Operational Research 168, 1999, 35-50.

[21] Sayeh, Dani, and Swain, TQM Management Culture within Libyan Organisations, Journal of Operations Management 25, 2005, 83-109.

[22] F. Tjiptono and D. Anastasia, Total Quality Management, Cetakan Kedua, (Yogyakarta, Indonesia: Andi Offset, 2003).

[23] F. Tjiptono, Manajemen Jasa (Yogyakarta, Indonesia: Penerbit Andi, 2002).

[24] M.N. Nasution, Manajemen Mutu Terpadu (Jakarta: Ghalia Indonesia, 2004).

[25] D.L. Goetsch and S.B. Davis, Introduction to Total Quality, Quality, Productivity, Competitiveness (Englewood: Prentice Hall International Inc., 1994) 121-138.

[26] M.N. Nasution, Manajemen Mutu Terpadu (Jakarta: Ghalia Indonesia, 2005).

[27] United States Department of Commerce. Malcolm Baldrige National Quality Award: Criteria For Performance Excellence (Gaithersburg: National Institute of Standards and Technology, 1997).

[28] S.P. Robbins, Organization Behavior, $9^{\text {th }}$ Edition (USA: Prentice Hall International Inc., 2007)

[29] L.M. Spencer and S.M. Spencer, Competence at Work, Human Resource Development Quarterly, 5(4), 1993, 391-395.

[30] Dess and Lumpkin, Action research: A handbook for practitioners (London: International Educational and Profesional Publisher, 2003). 
[31] D. Wibisono, Manajemen Kinerja (Indonesia: Penerbit Erlangga, 2006).

[32] G. Dessler, Manajemen Sumberdaya Manusia (Jakarta: PT. Prenhallindo, 2001).

[33] Schein, Organizational Culture \& Leadership (San Fransisco : Jossey-Bass Publisher, 1985), 14

[34] Baidoun, An Empirical Study of Critical Factors of TQM in Palestinian Organizations, Journal of Operations \& Production Management, 20(11), 2003, 1293-1312.

[35] Metri, TQM Critical Succes Factor for Construction Firms, India Management Development Institute, 10(2), 2005, 61-72

[36] Srismith, Quality Culture and Integrated Communications, Academy of Management Journal 20(3), $2005,439-453$.

[37] Z. Zhang, Developing an Instrument for Measuring TQM Implementation in a Chinese Context, 2000.

[38] Z. Zhang, A. Waszink, and J. Wijngaard, (1998). An Instrument for measuring TQM implementation for Chinese manufacturing companies, International Journal of Quality \& Reliability Management, 17(7), 1998, 730-755.

[39] Cheng Liu, The Relationship of Organizational Culture and Implementation of Total Quality Management in Construction Firms (-, 2007)

[40] Powell, Total Quality Management as Competitive Advantage: A Review and Empirical Study, Strategic Management Journal, 16(1), 1995, 15-37.

[41] J.D. Stemple, Job Satisfaction of High School Principals in Virginia, doctoral dissertation, Virginia Polytechnic Institute and State University, Blackburg, 2004.

[42] J.L. Arbuckle, Amos 16.0 User's Guide (Chicago:Small Waters Corporation, 2007).

[43] J.F. Hair, R.E. Anderson, R.L. Tatham, and W.C. Black, Multivariate Data Analysis (New York: Mamillan Publishing Company, 2006).

[44] J.F. Hair, R.E. Anderson, R.L. Tatham, and W.C. Black, Multivariate Data Analysis (Upper Saddle River: Prentice Hall, 1998).

[45] F. Augusty, Structural Equation Modeling Dalam Penelitian Manajemen (Semarang: BP Undip, 2000).

[46] Solimun, Multivariat Analysis: Structural Equation Modelling (SEM) Lisrel dan Amos (Malang, Indonesia: Fakultas MIPA Universitas Brawijaya, 2002).

[47] G.M. Maruyama, Basic of Structural Equation Modeling (Thousand Oaks: Sage Publishing, 1998).

[48] Stringer, Structural model evaluation and modification: An Interval estimation approach, Multivariate Behavioral Research, 25, 1998, 173-180.

[49] S. Hardjosoedarmo, Total Quality Management (Yogyakarta, Indonesia: Gramedia, 2004).

[50] Dean and Evans, Integrated manufacturing and job design: moderating effects of organizational inertia, Academy of Management Journal, 34(4), 1994, 776-804.

[51] Develin and Partners, Organisational innovation: a meta-analysis of effects of determinants and moderators. Academy of Journal Management, 34(3), 1989, 555-590.

[52] Scazzero and Stansfield, Organisational innovativeness: exploring the relationship between organizational determinants of innovation, types of innovations, and measures of organisational performance, Omega-International Journal of Management Science, 24(6), 1994, 631-647.

[53] Joiner, Total Quality Management and Performance: The Role of Organization Support and co-worker support (2007).

[54] S. Terziovski and Dow, The Business Value of Quality Management Systems Certification: Evidence from Australia and New Zealand (2003).

[55] Prajogo and Brown, The Relationship Between TQM Practices and Quality Performance and the Role of Formal TQM Programs: An Australian Emprical Study (2004). 